\title{
Cultivable mushroom growth-promoting bacteria and their impact on Agaricus blazei productivity
}

\author{
Li-Sen Young ${ }^{(1)}$, Jiunn-Nan Chu ${ }^{(2)}$, Asif Hameed ${ }^{(2)}$ and Chiu-Chung Young ${ }^{(2)}$
}

\begin{abstract}
(1)National Formosa University, Department of Biotechnology, oo 64, Wunhua Road, Huwei Township, Yunlin 632, Taiwan. E-mail: Isyoung69@nfu.edu.tw (2)National Chung Hsing University, College of Agriculture and Natural Resources, Department of Soil and Environmental Sciences, no 250, Kuo Kuang Road, Taichung 40227, Taiwan. E-mail: jnc@ms83.url.com.tw, asifbiology@gmail.com, ccyoung@mail.nchu.edu.tw
\end{abstract}

\begin{abstract}
The objective of this work was to identify growth-promoting bacteria isolated from Agaricus blazei and to evaluate their effect on mushroom mycelial growth and productivity. A total of $56 \mathrm{~A}$. blazei-associated bacterial isolates were obtained from casing soil and identified by $16 \mathrm{~S}$ rRNA gene sequencing. Bacteria were evaluated as to phosphate-solubilization ability, nitrogen-fixation capability, and secretion of cellulase. Superior isolates were tested for their to effect on A. blazei productivity, micelial growth, and on the contents of the polysaccharide-protein complex and of $\mathrm{N}, \mathrm{P}, \mathrm{K}, \mathrm{Ca}$, and $\mathrm{Mg}$. Bacterial isolates were identified as actinobacteria $(60 \%)$, firmicutes $(20 \%)$, and proteobacteria $(20 \%)$. Among them, ten isolates had phosphate-solubilization ability, eight showed nitrogen-fixation capability, and 12 isolates promoted A. blazei mycelium growth. Bacterial inoculation reduces time till harvest in up to 26 days, increases fresh mushroom yield up to $215 \%$, and increases total polysaccharide-protein complex content twofold when compared to the non-inoculated control. The actinobacteria group is the predominant $A$. blazei-associated phylum.
\end{abstract}

Index terms: Agaricus blazei, bioprospecting, fresh mushroom yield, polysaccharide-protein complex.

\section{Bactérias cultiváveis promotoras do crescimento do cogumelo e seu impacto sobre a produtividade de Agaricus blazei}

Resumo - O objetivo deste trabalho foi identificar bactérias promotoras de crescimento, isoladas de Agaricus blazei, e avaliar o seu efeito sobre o crescimento micelial e a produtividade do cogumelo. Um total de 56 isolados bacterianos associados a A. blazei foram obtidos a partir de solo de cobertura, e identificados por sequenciamento do gene $16 \mathrm{~S}$ rRNA. As bactérias foram avaliadas quanto à capacidade de solubilização de fosfato, à capacidade de fixação de nitrogênio e à secreção de celulases. Isolados superiores foram testados quanto a seus efeitos sobre a produtividade de $A$. blazei, o crescimento micelial, e os teores do complexo polissacarídeo-proteínas e os de N, P, K, Ca e Mg. Os isolados bacterianos foram identificados como actinobacteria (60\%), firmicutes $(20 \%)$ e proteobactéria (20\%). Entre eles, dez isolados tiveram capacidade de solubilização de fosfato, oito apresentaram capacidade de fixação de nitrogênio e 12 isolados promoveram o crescimento micelial de A. blazei. A inoculação bacteriana reduz o tempo até a colheita em até 26 dias, aumenta o rendimento de cogumelo fresco até $215 \%$ e aumenta em duas vezes o teor do complexo polissacarídeo-proteínas quando comparado ao controle não inoculado. O grupo das actinobacterias é o filo predominante associado a $\mathrm{A}$. blazei.

Termos para indexação: Agaricus blazei, bioprospecção, produção de cogumelos frescos, complexo polissacarídeo-proteínas.

\section{Introduction}

Plant root exudates influence the diversity and activity of rhizobacteria, and may play important roles in nutrient mobilization and plant growth (Kumar et al., 2012). Growth-promoting rhizobacteria (PGPR) in the vicinity of plant root tissues have been reported to stimulate plant growth (Laslo et al., 2012; Sessitsch et al., 2012; Young et al., 2013). However, the screening of mushroom growth-promoting bacteria (MGPB) for mushroom culturing is still limited.

Zarenejad et al. (2012) screened the casing layer of 14 edible mushroom farms and identified 23 strains that were potent MGPB. Further fieldwork indicated that Pseudomonas putida was the best suited growth-promoting inoculant for increasing Agaricus bisporus mushroom yield in production farms. In another study, bacteria were isolated from 
the mycelial surface of Pleurotus ostreatus and assessed as to their roles in the induction of fruiting body (Cho et al., 2003). The authors found that the inoculation of pure culture of the mycelium with strains of fluorescent Pseudomonas spp., isolated from the mycelial plane of commercially produced mushrooms, promoted the formation of primordia and enhanced the development of the basidiome of $P$. ostreatus. These studies strongly suggest that screening of specific bacteria may have beneficial applications for mushroom production and serve as a basis for future research.

Edible mushrooms with high amounts of protein, minerals, and vitamins are important components of many ethnic diets (Gbolagade et al., 2006). Agaricus blazei contains active organic compounds associated with the maintenance of human health and the healing of diseases. Pharmacological studies have shown that bioactive substances, such as polysaccharide-protein complexes (PSPC) from A. blazei, function as antioxidants, antimutagenics, antitumorigenics, and anticancer agents (Kimura et al., 2004; Firenzuoli et al., 2008). However, the harvesting time of $A$. blaze $i$ is relatively long (approximately 60 days) when compared to other related Agaricus sp., including A. bisporus (approximately 30 days) (Pardo-Gimenez et al., 2010; Chu et al., 2012). Attempts to improve A. blazei productivity have mainly focused on the application of different combinations of culture media and casing soils (Pardo-Gimenez et al., 2010; Chu et al., 2012). Young et al. (2012) studied six A. blazei-associated soil bacteria and successfully identified several beneficial microbes that could significantly improve $A$. blazei productivity and PSPC content. Therefore, it would be beneficial to characterize mushroom-associated microorganisms and to identify biological agents that can be used to decrease the time and energy required to culture A. blazei. Although metagenomic approaches are widely used in the characterization of microbial communities associated with various crop or soil systems, specific functions of those native microbes and their practical implications remain largely unexplored.

The objective of this work was to identify growth-promoting bacteria isolated from $A$. blazei casing soil and to evaluate their effect on mushroom mycelial growth and productivity.

\section{Materials and Methods}

The casing soil associated with $A$. blazei stipe was collected from an indoor farm located in Nantou, Taiwan (N23 ${ }^{\circ} 7^{\prime} 26^{\prime \prime}$, E120 58'29"). The physicochemical properties of the culture medium and loamy casing soil were previously described in Young et al. (2012) and are summarized in Table 1. The casing soil was soaked in sterile water at a ratio of $1: 1(\mathrm{w} / \mathrm{w})$ and shook for 0.5 hour at $25^{\circ} \mathrm{C}$. Aliquots $(100 \mathrm{ml})$ of the soil solution were plated on nutrient agar (HiMedia Laboratories, Mumbai, India) by the serial dilution method, and incubated at $25^{\circ} \mathrm{C}$ for three days. Pure cultures of morphologically different bacterial colonies were isolated and individually cultured on nutrient broth for DNA extraction with a Microbial DNA Isolation Kit Ultraclean, (MO BIO Laboratories, Inc., Carlsbad, CA, USA). The $16 \mathrm{~S}$ rRNA gene was amplified using 1F (5'-GAGTTTGATCATGGCTCAG-3') and 9R (5'-AAGGAGGTGATCCAACCGCA-3') universal primers (Edwards et al., 1989), with a PCR Master Mix reaction kit (GeneMark Technology Co., Ltd., Tainan, Taiwan) and a Prime Thermal Cycler (Techne Flexigene, Cambridge, UK). Amplification was set at the following conditions: $95^{\circ} \mathrm{C}$ for $5 \mathrm{~min}$, followed by 35 cycles of $95^{\circ} \mathrm{C}$ for $1 \mathrm{~min}, 60^{\circ} \mathrm{C}$ for $1 \mathrm{~min}, 72^{\circ} \mathrm{C}$ for $2 \mathrm{~min}$, and final extension at $72^{\circ} \mathrm{C}$ for $7 \mathrm{~min}$. DNA fragments of approximately 1,500 bp were purified using a QIAquick Gel Extraction Kit (Qiagen, Hilden, Germany) and were sequenced as described in Young et al. (2012). The cycle sequencing primers used were: 3F: 5'-CCTACGGGAGGCAGCAG-3', 4R: 5'-TTA CCGCGGCTGCTGGCAC-3', and 5F: 5'-AAACTC AAATGAATTGACGGGG-3' (Edwards et al., 1989). The 16S rRNA gene sequences (approximately 1,500 continuous nucleotides) were analyzed using EzBioCloud (2013). Only the identity and accession number that showed the highest level of similarity in the 16S rRNA gene sequence was considered (Table 2).

Cellulase activity of bacterial isolates was determined by incubating in medium containing $0.5 \%$ carboxymethyl cellulose for 24 hours and subsequent staining with $0.1 \%$ Congo red in triplicates (Sakthivel et al., 2010). Phosphate-solubilization activity was performed using Pikovskaya's medium supplemented with $\mathrm{Ca}_{3}\left(\mathrm{PO}_{4}\right)_{2}, \mathrm{AlPO}_{4}$ or $\mathrm{FePO}_{4}$, and the presence of clearing zone formation was observed in triplicates (Husen, 2003). Nitrogen-fixation capabilities were assessed using the acetylene reduction assay (Koch 
\& Evans, 1966). Briefly, bacteria were inoculated in $10 \mathrm{~mL}$ nitrogen-free bromothymol blue $(\mathrm{Nfb})$ medium using a $30 \mathrm{~mL}$ screw cap test tube for 24 hours. Afterwards, $3 \mathrm{~mL}$ of enclosed air were replaced with $3 \mathrm{~mL}$ of acetylene. The reaction took place at room temperature for 24 hours. A total of $0.5 \mathrm{~mL}$ of air from the test tube was extracted with a syringe and injected in a gas chromatograph, model 163 (Hitachi, Ltd., Tokyo, Japan) equipped with a flame ionization detector in order to analyze ethylene quantity. The separation tube was loaded with 80-100 mesh Porapark R, (Hitachi, Ltd., Tokyo, Japan); the injector was set at $100^{\circ} \mathrm{C}$; the chamber was set at $60^{\circ} \mathrm{C} ; \mathrm{H}_{2}$ and $\mathrm{N}_{2}$ gas flow was set at $40 \mathrm{~mL} \mathrm{~min}^{-1}$; and air flow was set at $0.4 \mathrm{~mL} \mathrm{~min}^{-1}$.

Table 1. Physicochemical properties of loamy casing soil and sawdust medium used to culture Agaricus blazei.

\begin{tabular}{|c|c|c|c|c|c|c|c|c|c|c|c|}
\hline \multirow[t]{2}{*}{ Material } & $\mathrm{pH}$ & EC & $f$ & WHC & Ash & $\mathrm{OM}$ & $\mathrm{OC}$ & $\mathrm{N}$ & $\mathrm{C} / \mathrm{N}$ & $\mathrm{BD}$ & PD \\
\hline & & $\left(\mu \mathrm{S} \mathrm{cm}^{-1}\right)$ & & ----- & & $-(\%)-$ & & ------- & & \multicolumn{2}{|c|}{--- $\left(\mathrm{g} \mathrm{cm}^{-3}\right)$} \\
\hline Sawdust & 7.47 & 2.72 & nd & nd & 15.0 & 79.2 & 46.0 & 2.58 & 17.8 & nd & nd \\
\hline LS & 5.82 & 177 & 48.2 & 147 & 94.5 & 4.35 & 2.29 & 0.10 & 22.9 & 1.32 & 2.55 \\
\hline
\end{tabular}

EC, electric conductivity; $f$, porosity; WHC, water holding capacity; OM, organic matter; OC, organic carbon; $\mathrm{N}$, total nitrogen; $\mathrm{C} / \mathrm{N}$, total nitrogen carbon ratio; $\mathrm{BD}$, bulk density; $\mathrm{PD}$, particle density; nd, not determined; LS, loamy soil/loamy, mixed, non acid, hyperthermic, Typic Udorthent.

Table 2. Identification of bacterial strains isolated from Agaricus blazei casing soil based on most similar 16S rRNA gene sequence.

\begin{tabular}{|c|c|c|c|c|c|}
\hline Strain code & Scientific name of closest match & Accession №. & Strain code & Scientific name of closest match & Accession №. \\
\hline$\alpha$-proteobacteria & & & SBCK209 & Microbacterium agarici ${ }^{(1)}$ & FJ807673.1 \\
\hline SBCK208 & Ochrobactrum anthropi & AB683957.1 & 12309 & Microbacterium humi $i^{(1)}$ & FJ865215.1 \\
\hline 12310 & Ochrobactrum lupine & AY457038.1 & SBABM103 & Microbacterium hominis & AM181504.1 \\
\hline SBABM117 & Agaricicola taiwanensis $^{(1)}$ & FJ594057.1 & SBCK201 & Microbacterium resistens & AY244784.1 \\
\hline$\beta$-proteobacteria & & & 16104 & Microbacterium sp. XT11 & DQ350882.1 \\
\hline SBCK2032 & Advenella incenata & AM944734.1 & 5104 & Microbacterium pseudoresistens $^{(1)}$ & FJ865214.1 \\
\hline$\gamma$-proteobacteria & & & 12306 & Micrococcus luteus & HM584259.1 \\
\hline SBABM109 & Enterobacter ludwigii & AJ853891.1 & 16107 & Microlunatus soli ${ }^{(1)}$ & FJ807672.1 \\
\hline JN17 & Pseudomonas alcalophila ${ }^{(2)}$ & AB030583.1 & 10203 & Mycobacterium fortuitum subsp. Fortuitum & NR042914.1 \\
\hline SBABM101 & Pseudomonas putida & DQ095207.1 & 12302 & Mycobacterium fortuitum & FR733720.1 \\
\hline JN16 & Pseudomonas resinovorans ${ }^{(2)}$ & AJ308314.1 & 5103 & Mycobacterium porcinum & AF480588.1 \\
\hline 10208 & Serratia marcescens & AB614497.1 & SBCK246 & Streptomyces erythrogriseus & EU301830.1 \\
\hline 16115 & Serratia marcescens subsp. Sakuensis & JN408199.1 & SBBK306 & Streptomyces malachitofuscus & AB184282.1 \\
\hline 12314 & Serratia rubidaea & GQ332600.1 & SBCK250 & Streptomyces rubrogriseus & AB184681.1 \\
\hline Actinobacteria & & & SBCK247 & Streptomyces sp. CNR885 PL04 & DQ448739.1 \\
\hline SBBK303 & Actinomycetales bacterium $\mathrm{N} 12$ & AY944250.1 & SBABMe2 & Streptomyces speibonae & AF452714.1 \\
\hline SBCK206 & Actinomycetales bacterium N16 & AY944253.1 & SBCK249 & Streptomyces variegates & AB184688.1 \\
\hline SBABM116 & Agrococcus jenensis & AM410679.1 & 12305 & Streptomyces violaceorubidus & AB184689.1 \\
\hline SBBK310 & Arthrobacter crystallopoietes & JQ687119.1 & 10207 & Tsukamurella tyrosinosolvens & AY254699.1 \\
\hline JN12 & Arthrobacter sp. K4 10C(2) & EF612294.1 & Firmicutes & & \\
\hline SBCK207 & Brachybacterium nesterenkovii & X91033.1 & SBABM107 & Bacillus bataviensis & AM237399.1 \\
\hline 5107 & Brachybacterium paraconglomeratum & JQ712514.1 & SBABM106 & Bacillus circulans & АВ006923.1 \\
\hline 16112 & Brevibacterium linens & $\mathrm{AB} 211980.2$ & SBABM122 & Bacillus firmus & AB006925.1 \\
\hline 10205 & Brevibacterium oceani & AM158905.2 & SBBK315 & Bacillus flexus & AB021185.1 \\
\hline 12308 & Curtobacterium citreum & AM410690.1 & SBABM113 & Bacillus humi & AJ627210.1 \\
\hline SBCK202 & Gordonia hydrophobica & X87340.1 & SBBK305 & Bacillus megaterium & AB006930.1 \\
\hline 12311 & Leifsonia kribbensis & EF466129.1 & SBBK312 & Bacillus niacin & AB680904.1 \\
\hline SBBK3P1 & Microbacterium arabinogalactanolyticum & AB004715.1 & SBABM108 & Bacillus pocheonensis & AB245377.1 \\
\hline 12312 & Microbacterium barkeri & X77446.1 & JN05 & Bacillus psychrodurans $^{(2)}$ & JF970581.1 \\
\hline $\mathrm{JN} 10$ & Microbacterium esteraromaticum $^{(2)}$ & GU111572.1 & JN03 & Exiguobacterium $\mathrm{sp}^{(2)}$ & HQ848274.1 \\
\hline SBCK209 & Microbacterium agarici ${ }^{(1)}$ & FJ807673.1 & SBCK210 & $\begin{array}{l}\text { Staphylococcus saprophyticus subsp } \\
\text { Saprophyticus }\end{array}$ & JQ795864.1 \\
\hline
\end{tabular}

${ }^{(1)}$ Identified new genus or species in this research. ${ }^{(2)}$ Previously published in Young et al. (2012). 
Duncan's multiple range test was used as the statistical method for measuring the three replicates.

The effect of the 56 individual isolates on A. blazei mycelium growth was tested as described below. A $0.5-\mathrm{cm}$ diameter block of $A$. blazei mycelium was spotted on a Difco potato dextrose agar (Voigt Global Distribution Inc., Lawrence, KS, USA) plate along with an individual bacterial strain, which was drawn in a line approximately $2 \mathrm{~cm}$ away from the spotted A. blazei mycelium block with a sterilized inoculation loop. After seven days at $28^{\circ} \mathrm{C}$, with a 12 hour/ 12 hour light/dark cycle, the average mycelium diameter of A. blazei was measured in triplicates and compared to the control without microbial inoculation (Young et al., 2012).

Fresh A. blazei was cultured on sterilized wheat to produce A. blazei grain spawn (Chu et al., 2012). Sterilized sawdust medium (Chu et al., 2012) was evenly packed in bag $\operatorname{logs}$ in a $250 \mathrm{~mL}$ pot with a total weight of $100 \mathrm{~g}$. The moisture content of the sawdust medium was $57 \%$. Two grams of A. blazei grain spawn were inoculated on sterilized sawdust medium and placed in an incubator at $28^{\circ} \mathrm{C}$ for spawning. The light intensity in the growth chamber was $20 \pm 2$ lx, measured with the TES-1335 Digital Light Meter (Tes Electrical Electronic Corp., Taipei, Taiwan). After complete spawning (one month), loamy soil loamy, mixed, nonacid, hyperthermic, Typic Udorthent (Food and Agriculture Organization of the United Nations, 1988) - was covered on top of the medium to a depth of 2-2.5 cm (Chu et al., 2012). The casing soil was sterilized before use $\left(121^{\circ} \mathrm{C}, 1.033 \mathrm{~kg} \mathrm{~cm}^{-2}\right.$, 1 hour for three times) to avoid possible microbial contaminants and was subsequently inoculated with individual bacterial strains. Seven bacterial isolates were chosen as to their effects on A. blazei productivity. Five milliliters of nutrient broth-cultured bacteria $\left(10^{9} \mathrm{cfu} \mathrm{mL}^{-1}\right.$, determined using the serial dilution method) were evenly applied directly on top of the casing soil, weekly until harvest. The same volume of bacteria-free nutrient broth was applied on the casing soil of the non-inoculated control. Each experiment was conducted with three replicates, in a randomized block design.

Harvesting time of the fruiting body took place when the mushroom reached its highest biomass, which occurs during the immature stage, when the veil membrane is enclosed and the gills are intact (Mendonça et al.,
2005; Pokhrel \& Ohga, 2007; Chu et al., 2012). Total mushroom fresh yield (g per pot) and PSPC content were measured from the first mushroom flush. PSPC content was determined according to Sarangi et al. (2006) and the ones of N, P, K, Ca, and Mg were measured using double acid $\left(\mathrm{HClO}_{4}: \mathrm{HNO}_{3}=1: 4\right.$, $\mathrm{v} / \mathrm{v}$ ) analysis (Jones Junior, 2001). All standards were purchased from Sigma-Aldrich Co. (St. Louis, MO, USA). Data were analyzed statistically using CoStat's statistical procedures (CoHort Software, Pacific Grove, CA, USA), and means were compared by Duncan's multiple range test, at $5 \%$ probability.

\section{Results and Discussion}

Bacterial count in A. blazei-associated soil from triplicates was estimated at approximately $1.3 \times 10^{6} \mathrm{cfu} \mathrm{g}^{-1}$. A total of $56 \mathrm{~A}$. blazei-associated bacteria isolates were identified in the present study (Table 2). Of these, 34 were identified as actinobacteria $(60 \%), 11$ as firmicutes $(20 \%)$, three as $\alpha$-proteobacteria $(5 \%)$, one as $\beta$-proteobacteria ( $2 \%)$, and seven as $\gamma$-proteobacteria (13\%) phyla. Among them, Agaricicola taiwanensis, Microbacterium agarici, M. humi, M. pseudoresistens, and Microlunatus soli were considered a novel genus or a new species (Chu et al., 2010; Kämpfer et al., 2010; Young et al., 2010). Zarenejad et al. (2012) also evaluated mushroom growth-promoting bacteria (MGPB) from soil samples of $A$. bisporus mushroom farms. Unfortunately, the phylum or scientific names of the 274 bacterial isolates were not described in their work for comparison, except for $P$. putida, which showed positive effects on A. bisporus production.

Actinobacteria isolates belonged to 14 genera, making it the most phylogenetically diverse group. Among them, Microbacterium sp. (29\%) and Streptomyces sp. (21\%) were dominant, which have been reported to be active indole-3-acetic acid (IAA) phytohormone producers and biological control agents, respectively (Saharan \& Nehra, 2011). Notably, Arthrobacter sp. and Mycobacterium sp. have been described as important non-symbiotic nitrogen-fixers and as being able to exert beneficial effects on plant growth (Tilak et al., 2005). Within the identified firmicute phylum, $82 \%$ belong to the genus Bacillus, which is the most abundant genus in the rhizosphere. The growth-promoting activity and 
the plant disease suppressing capabilities of some of these strains have resulted in a broad knowledge of the mechanisms involved (Probanza et al., 2002). The phylum proteobacteria accommodates Enterobacter, Pseudomonas, and Serratia genera, which are known to be associated with the plant rhizosphere and are able to exert growth-promoting effects (Tilak et al., 2005; Zarenejad et al., 2012). In fact, Pseudomonas sp. are ubiquitous bacteria in agricultural soils and have many traits that make them well suited as growth-promoting bacteria (Saharan \& Nehra, 2011). Therefore, the A. blazei-associated bacteria identified here could prove useful for the development of biotechnological products for the improvement of $A$. blazei production.

Functional characterization revealed that $29 \%$ of the bacterial isolates were able to secrete cellulase (Figure 1; Table 3). In addition, other growth promotion capabilities were tested for further potential development into MGPB. Approximately $18 \%$ of the isolates confer phosphate-solubilization and $14 \%$ had nitrogen-fixation ability. Among the A. blazei-associated bacteria, $21 \%$ of the isolates promote $A$. blazei mycelium growth, whereas $14 \%$ inhibit its growth. Although there are no known reports on the usage of Gordonia hydrophobica

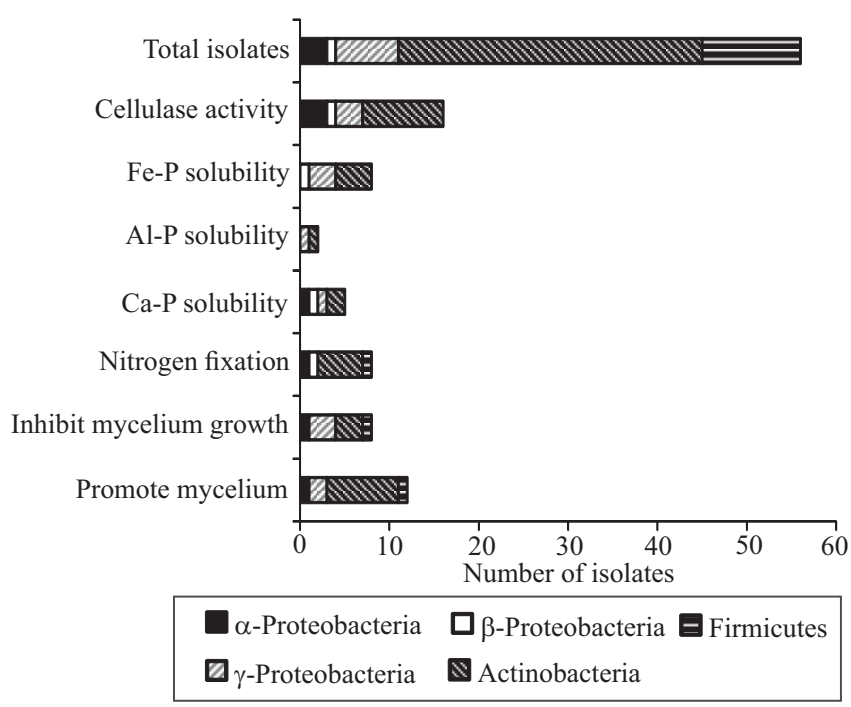

Figure 1. Frequency and affiliation of isolates from Agaricus blazei casing soil conferring various metabolic and growth promoting activities. The column of total isolates shows the phylogenetic affiliation of each population for comparison.
(SBCK202) in agriculture, it was able to solubilize all three forms of insoluble P (Fe-P, Ca-P, and Al-P) and acted as a nitrogen fixer in the present study. This observation merits further investigation for its conversion into beneficial microorganisms in agricultural practices. Strains such as A. taiwanensis (SBABM117), $M$. agarici (SBCK209), and $M$. soli (16107) were considered to be novel nitrogen fixers as well. Moreover, A. taiwanensis confers phosphate-solubilization and cellulase secreting abilities. Conventional culturing of A. blazei utilizes plant residues, such as sawdust or rice straw, as a medium for initial spawning of the mycelium (Chu et al., 2012). Since A. blaze i is a secondary saprophyte, bacterial isolates that could degrade cellulose may be beneficial to mycelial growth. Promotion of mycelium growth by inoculants has been reported to enhance mushroom productivity (Kim et al., 2008). Overall, the above data provided benchmarks to select and shortlist seven isolates from the total of 56 to test their effects on A. blazei productivity.

Actinomycetales bacterium N12, Advenella incenata, A. taiwanensis, Curtobacterium citreum, G. hydrophobica, M. humi, and Streptomyces violaceorubidus were selected to be tested. Sterilized soil casing without bacterial inoculation (control) resulted in a harvest time of 67 days after casing (Table 4). Inoculation of Actinomycetales bacterium N12 or S. violaceorubidus in the casing soil increased the time till harvest, whereas the inoculation of the other five isolates resulted in reductions ranging from 21 to 26 days, compared to control. Among the seven tested isolates, A. taiwanensis and M. humi were tested as to their effects on mycelium growth in a co-culture plate assay, which resulted in shorter harvesting time. The isolates $A$. incenata, C. citreum, and $G$. hydrophobica were neutral to the mycelium growth of $A$. blazei but also reduced the time till harvest. These results suggest that the promotion of mycelium growth does not necessarily reflect faster fruiting body development. Other studies are necessary to identify unknown biotic factors (e.g. microbial exudates) that may contribute more significantly to mushroom development.

Regarding mushroom yield in the first flush, inoculation of all seven isolates individually exhibited significant increase in total fresh yield, ranging from 170 to $215 \%$ of the non-inoculated control. Again, this 
Table 3. Functional characterization of bacterial strains isolated from Agaricus blazei casing soil.

\begin{tabular}{|c|c|c|c|c|c|c|c|}
\hline Strain code & Cellulase & Fe-P & Al-P & $\mathrm{Ca}-\mathrm{P}$ & $\mathrm{N}_{2}$ fixation $\left(\mu \mathrm{m} \mathrm{C}_{2} \mathrm{H}_{2}\right.$ per hour) & Inhibit mycelium & Promote mycelium \\
\hline \multicolumn{8}{|l|}{$\alpha$-proteobacteria } \\
\hline SBCK208 & $\sqrt{ }(1)$ & nd & nd & nd & nd & $\sqrt{ }$ & nd \\
\hline 12310 & $\sqrt{ }$ & nd & nd & nd & nd & nd & nd \\
\hline SBABM117 & $\sqrt{ }$ & nd & nd & $\sqrt{ }$ & 3136 & nd & $\sqrt{ }$ \\
\hline \multicolumn{8}{|l|}{$\beta$-proteobacteria } \\
\hline SBCK2032 & $\sqrt{ }$ & $\sqrt{ }$ & nd & $\sqrt{ }$ & 703 & nd & nd \\
\hline \multicolumn{8}{|l|}{$\gamma$-proteobacteria } \\
\hline SBABM109 & nd & nd & nd & nd & nd & nd & nd \\
\hline JN17 & nd & nd & nd & nd & nd & nd & $\sqrt{ }$ \\
\hline SBABM101 & nd & nd & nd & nd & nd & nd & nd \\
\hline JN16 & nd & nd & nd & nd & nd & nd & $\sqrt{ }$ \\
\hline 10208 & $\sqrt{ }$ & $\sqrt{ }$ & nd & nd & nd & $\sqrt{ }$ & nd \\
\hline 16115 & $\sqrt{ }$ & $\sqrt{ }$ & nd & $\sqrt{ }$ & nd & $\sqrt{ }$ & nd \\
\hline 12314 & $\sqrt{ }$ & $\sqrt{ }$ & $\sqrt{ }$ & nd & nd & $\sqrt{ }$ & nd \\
\hline \multicolumn{8}{|l|}{ Actinobacteria } \\
\hline SBBK303 & $\sqrt{ }$ & $\sqrt{ }$ & nd & nd & 2139 & nd & nd \\
\hline SBCK206 & nd & nd & nd & $\sqrt{ }$ & nd & nd & nd \\
\hline SBABM116 & nd & nd & nd & nd & nd & nd & nd \\
\hline SBBK310 & nd & nd & nd & nd & nd & nd & nd \\
\hline $\mathrm{JN} 12$ & nd & nd & nd & nd & nd & nd & $\sqrt{ }$ \\
\hline SBCK207 & nd & nd & nd & nd & nd & nd & nd \\
\hline 5107 & nd & nd & nd & nd & nd & nd & nd \\
\hline 16112 & $\sqrt{ }$ & nd & nd & nd & nd & nd & $\sqrt{ }$ \\
\hline 10205 & $\sqrt{ }$ & $\sqrt{ }$ & nd & nd & nd & $\sqrt{ }$ & nd \\
\hline 12308 & nd & nd & nd & nd & nd & nd & nd \\
\hline SBCK202 & $\sqrt{ }$ & $\sqrt{ }$ & $\sqrt{ }$ & $\sqrt{ }$ & 9864 & nd & nd \\
\hline 12311 & nd & nd & nd & nd & nd & nd & nd \\
\hline SBBK3P1 & nd & nd & nd & nd & nd & nd & nd \\
\hline 12312 & nd & nd & nd & nd & nd & nd & nd \\
\hline JN10 & nd & nd & nd & nd & nd & nd & nd \\
\hline SBCK209 & nd & nd & nd & nd & 2124 & nd & nd \\
\hline 12309 & nd & nd & nd & nd & nd & nd & $\sqrt{ }$ \\
\hline SBABM103 & nd & nd & nd & nd & nd & nd & nd \\
\hline SBCK201 & $\sqrt{ }$ & nd & nd & nd & nd & nd & $\sqrt{ }$ \\
\hline 16104 & nd & nd & nd & nd & nd & nd & $\sqrt{ }$ \\
\hline 5104 & nd & nd & nd & nd & nd & nd & nd \\
\hline 12306 & $\sqrt{ }$ & nd & nd & nd & nd & nd & $\sqrt{ }$ \\
\hline 16107 & $\sqrt{ }$ & nd & nd & nd & 4481 & nd & $\sqrt{ }$ \\
\hline 10203 & nd & nd & nd & nd & nd & $\sqrt{ }$ & nd \\
\hline 12302 & $\sqrt{ }$ & nd & nd & nd & nd & nd & $\sqrt{ }$ \\
\hline 5103 & nd & nd & nd & nd & nd & nd & nd \\
\hline SBCK246 & nd & nd & nd & nd & nd & nd & nd \\
\hline SBBK306 & nd & nd & nd & nd & nd & nd & nd \\
\hline SBCK250 & nd & nd & nd & nd & nd & nd & nd \\
\hline SBCK247 & nd & nd & nd & nd & nd & nd & nd \\
\hline SBABMe2 & nd & nd & nd & nd & nd & nd & nd \\
\hline SBCK249 & nd & nd & nd & nd & nd & nd & nd \\
\hline 12305 & $\sqrt{ }$ & $\sqrt{ }$ & nd & nd & 6658 & nd & nd \\
\hline 10207 & nd & nd & nd & nd & nd & $\sqrt{ }$ & nd \\
\hline \multicolumn{8}{|l|}{ Firmicutes } \\
\hline SBABM107 & nd & nd & nd & nd & nd & nd & nd \\
\hline SBABM106 & nd & nd & nd & nd & nd & nd & nd \\
\hline SBABM122 & nd & nd & nd & nd & nd & nd & nd \\
\hline SBBK315 & nd & nd & nd & nd & nd & nd & nd \\
\hline SBABM113 & nd & nd & nd & nd & nd & nd & nd \\
\hline SBBK305 & nd & nd & nd & nd & nd & nd & $\sqrt{ }$ \\
\hline SBBK312 & nd & nd & nd & nd & nd & nd & nd \\
\hline SBABM108 & nd & nd & nd & nd & nd & nd & nd \\
\hline JN05 & nd & nd & nd & nd & nd & nd & nd \\
\hline JN03 & nd & nd & nd & nd & nd & nd & nd \\
\hline SBCK 210 & nd & nd & nd & nd & 1791 & $\sqrt{ }$ & nd \\
\hline
\end{tabular}

$(1) \sqrt{ }$ indicates bacteria with the associated function. $n d$, not detected. 
result does not correlate with promotion of mycelium growth, as reported in other edible mushrooms (Kim et al., 2008). It is interesting to note that P. putida was the best suited growth-promoting inoculant for increasing A. bisporus mushroom yield (Zarenejad et al., 2012). However, in a previous report, inoculation of $P$. resinovorans $(103 \%$ of the non-inoculated control) and P. alcaliphila (74\% of the non-inoculated control) did not improve $A$. blazei productivity (Young et al., 2012). Future works on possible microbial inducing substances of fruiting body and on different combinations of bacterial isolates should be conducted in order to determine the relation of MGPB with mushroom development.

Inoculation of $G$. hydrophobica in the casing soil significantly increased PSPC content when compared to that of the non-inoculated control (Table 4).
Inoculations of the other six isolates had no effect or showed slight decrease in PSPC content in comparison to that of the control. However, the increase in fresh yield from the first mushroom flush in most treatments can boost the total extractable PSPC content to almost twofold of the control.

Total $\mathrm{N}$ content in all inoculation treatments, except $S$. violaceorubidus, showed no significant difference when compared to the non-inoculated control (Table 5). However, $\mathrm{P}, \mathrm{K}, \mathrm{Mg}$, and Ca contents in the majority of the inoculated treatments were higher than those of the non-inoculated control. P-solubilization or nitrogen-fixation ability of the isolates did not correlate with increased contents of $\mathrm{P}$ or $\mathrm{N}$ in the mushroom. However, the growth promotion ability of these $A$. blazei-associated bacteria increased overall fresh yield (Ebadi et al., 2012).

Table 4. Effect of bacterial inoculation in loamy casing soil on harvesting time, fresh yield, and polysaccharide protein complex (PSPC) content of Agaricus blazei(1).

\begin{tabular}{|c|c|c|c|c|c|}
\hline \multirow[t]{2}{*}{ Inoculation treatment ${ }^{(2)}$} & \multirow{2}{*}{$\begin{array}{c}\text { Days of first } \\
\text { harvest after casing }\end{array}$} & \multicolumn{2}{|c|}{ Mushroom fresh yield } & \multicolumn{2}{|c|}{ PSPC content } \\
\hline & & (g per pot) & $(\%)^{(3)}$ & $\left(\mathrm{g} \mathrm{kg}^{-1}\right)$ & $(\%)$ \\
\hline Actinomycetales bacterium N12 & $98 \mathrm{a}$ & $20.7 b c$ & 185 & $4.44 \mathrm{c}$ & 91 \\
\hline Advenella incenata & $56 \mathrm{c}$ & $19.0 \mathrm{c}$ & 170 & $4.62 \mathrm{c}$ & 94 \\
\hline Agaricicola taiwanensis & $45 \mathrm{~d}$ & $23.0 \mathrm{ab}$ & 205 & $5.00 \mathrm{~b}$ & 102 \\
\hline Curtobacterium citreum & $42 \mathrm{e}$ & $23.1 \mathrm{ab}$ & 206 & $4.81 b$ & 98 \\
\hline Gordonia hydrophobica & $46 \mathrm{~d}$ & $22.5 b$ & 201 & $5.17 \mathrm{a}$ & 106 \\
\hline Microbacterium humi & $41 \mathrm{e}$ & $24.1 \mathrm{a}$ & 215 & $4.80 \mathrm{~b}$ & 98 \\
\hline Streptomyces violaceorubidus & $99 \mathrm{a}$ & $20.9 b$ & 187 & $4.57 \mathrm{c}$ & 93 \\
\hline Control $^{(2)}$ & $67 b$ & $11.2 \mathrm{~d}$ & 100 & $4.89 \mathrm{~b}$ & 100 \\
\hline
\end{tabular}

${ }^{(1)}$ Data followed by equal letters, in the rows, do not differ by Duncan's multiple range test, at $5 \%$ probability. ${ }^{(2)}$ Sterile soil without inoculation. ${ }^{(3)}$ The percentages following the numbers represent the increase or reduction of variables in relation to the non inoculated control. Mushroom fresh yield and PSPC content were analyzed using first flush harvest.

Table 5. Effect of microbe inoculation in loamy casing soil on inorganic element concentrations in fruiting bodies from first flush of Agaricus blazei $i^{(1)}$.

\begin{tabular}{|c|c|c|c|c|c|}
\hline Inoculation treatment ${ }^{(2)}$ & $\mathrm{N}$ & $\mathrm{P}$ & K & $\mathrm{Mg}$ & $\mathrm{Ca}$ \\
\hline & & & $\left(\mathrm{mg} \mathrm{g}^{-1}\right)$ & & \\
\hline Actinomycetales bacterium N12 & $105 \mathrm{a}$ & $41.9 \mathrm{~d}$ & $74.5 b$ & $1.37 \mathrm{c}$ & $119 \mathrm{e}$ \\
\hline Advenella incenata & $99 \mathrm{ab}$ & $46.5 \mathrm{a}$ & $67.9 \mathrm{c}$ & $1.53 \mathrm{a}$ & $194 c$ \\
\hline Agaricicola taiwanensis & $101 \mathrm{ab}$ & $47.3 \mathrm{a}$ & $81.3 \mathrm{a}$ & $1.57 \mathrm{a}$ & $171 d$ \\
\hline Curtobacterium citreum & $105 \mathrm{a}$ & $46.5 \mathrm{a}$ & $79.5 \mathrm{a}$ & $1.53 \mathrm{a}$ & $218 b$ \\
\hline Gordonia hydrophobica & $99 \mathrm{ab}$ & $45.1 \mathrm{~b}$ & $75.8 \mathrm{~b}$ & $1.47 \mathrm{~b}$ & $183 c$ \\
\hline Microbacterium humi & $101 \mathrm{a}$ & $47.9 \mathrm{a}$ & $79.9 \mathrm{a}$ & $1.53 \mathrm{a}$ & $258 \mathrm{a}$ \\
\hline Streptomyces violaceorubidus & $96 b$ & $42.0 \mathrm{~d}$ & $74.5 b$ & $1.40 \mathrm{c}$ & $129 \mathrm{e}$ \\
\hline Control $^{(2)}$ & $109 \mathrm{a}$ & $43.8 \mathrm{c}$ & $69.8 \mathrm{c}$ & $1.40 \mathrm{c}$ & $135 \mathrm{e}$ \\
\hline
\end{tabular}

${ }^{(1)}$ Means followed by equal letters do not differ by Duncan's multiple range test, at 5\% probability. ${ }^{(2)}$ Control, sterile soil without inoculation. All microbe tests were inoculated on sterile soil. Sawdust medium was used for culturing of A. blazei in all tests. 


\section{Conclusions}

1. Actinobacteria is the predominant Agaricus blazei-associated soil bacteria phylum.

2. Mushroom growth-promoting bacteria isolates significantly reduce $A$. blazei time till harvest up to 26 days, increase mushroom fresh yield up to $215 \%$, and increase total polysaccharide-protein complex content twofold when compared to that of the non-inoculated control.

\section{Acknowledgements}

To National Science Council and Council of Agriculture of Taiwan, for financial support.

\section{References}

CHO, Y.S.; KIM, J.S.; CROWLEY, D.E.; CHO, B.G. Growth promotion of the edible fungus Pleurotus ostreatus by fluorescent pseudomonads. FEMS Microbiology Letters, v.218, p.271-276, 2003. DOI: 10.1016/S0378-1097(02)01144-8.

CHU, J.-N.; ARUN, A.B.; CHEN, W.-M.; CHOU, J.-H.; SHEN, F.-T.; REKHA, P.D.; KÄMPFER, P.; YOUNG, L.-S.; LIN, S.-Y.; YOUNG, C.-C. Agaricicola taiwanensis gen. nov., sp. nov., an alphaproteobacterium isolated from the edible mushroom Agaricus blazei. International Journal of Systematic and Evolutionary Microbiology, v.60, p.2032-2035, 2010. DOI: 10.1099/ ijs.0.016485-0.

CHU, J.-N.; YOUNG, C.-C.; TAN, C.-C.; WU, S.-P.; YOUNG, L.-S. Improvement of productivity and polysaccharide-protein complex in Agaricus blazei. Pesquisa Agropecuária Brasileira, v.47, p.96-102, 2012. DOI: 10.1590/S0100-204X2012000100013.

EBADI, A.; ALIKHANI, H.A.; RASHTBARI, M. Effect of plant growth promoting bacteria (PGPR) on the morpho-physiological properties of button mushroom Agaricus bisporus in two different culturing beds. International Research Journal of Basic and Applied Sciences, v.3, p.203-212, 2012.

EDWARDS, U.; ROGALL, T.; BLOCKER, H.; EMDE, M.; BOTTGER, E.C. Isolation and direct complete nucleotide determination of entire genes. Characterization of a gene coding for 16S ribosomal RNA. Nucleic Acids Research, v.17, p.7843-7853, 1989. DOI: $10.1093 / \mathrm{nar} / 17.19 .7843$.

EZBIOCLOUD. EzTaxon-e. Available at: <http://eztaxon-e. ezbiocloud.net/ezt_results>. Accessed on: 12 Mar. 2013.

FOOD AND AGRICULTURE ORGANIZATION OF THE UNITED NATIONS. Soil map of the world. FAO: Rome, 1988. (FAO. World soil resources report, 60).

FIRENZUOLI, F.; GORI, L.; LOMBARDO, G. The medicinal mushroom Agaricus blazei Murrill: review of literature and pharmaco-toxicological problems. Evidence-based Complementary and Alternative Medicine, v.5, p.3-15, 2008. DOI: $10.1093 /$ ecam/nem007.
GBOLAGADE, J.; AJAYI, A.; OKU, I.; WANKASI, D. Nutritive value of common wild edible mushrooms from southern Nigeria. Global Journal of Biotechnology and Biochemistry, v.1, p.16-21, 2006.

HUSEN, E. Screening of soil bacteria for plant growth promotion activities in vitro. Indonesian Journal of Agricultural Sciences, v.4, p.27-31, 2003.

JONES JUNIOR, J.B. Laboratory guide for conducting soil tests and plant analysis. Boca Raton: CRC Press, 2001. DOI: $10.1201 / 9781420025293$.

KÄMPFER, P.; YOUNG， C.-C.; BUSSE，H.-J.; CHU, J.N.; SCHUMANN, P.; ARUN, A.B.; SHEN, F.T.; REKHA, P.D. Microlunatus soli sp. nov., isolated from soil. International Journal of Systematic and Evolutionary Microbiology, v.60, p.824-827, 2010. DOI: 10.1099/ijs.0.013540-0.

KIM, M.K.; MATH, R.K.; CHO, K.M.; SHIN, K.J.; KIM, J.O.; RYU, J.S.; LEE, Y.H.; YUN, H.D. Effect of Pseudomonas sp. P7014 on the growth of edible mushroom Pleurotus eryngii in bottle culture for commercial production. Bioresource Technology, v.99, p.3306-3308, 2008. DOI: 10.1016/j.biortech.2007.06.039.

KIMURA, Y.; KIDO, T.; TAKAKU, T.; SUMIYOSHI, M.; BABA, $\mathrm{K}$. Isolation of an anti-angiogenic substance from Agaricus blazei Murill: its antitumor and antimetastatic actions. Cancer Science, v.95, p.758-764, 2004. DOI: 10.1111/j.1349-7006.2004. tb03258.x.

KOCH, B.; EVANS, H.J. Reduction of acetylene to ethylene by soybean root nodules. Plant Physiology, v.41, p.1748-1750, 1966. DOI: $10.1104 /$ pp.41.10.1748.

KUMAR, G.; KANAUJIA, N.; BAFANA, A. Functional and phylogenetic diversity of root-associated bacteria of Ajuga bracteosa in Kangra valley. Microbiological Research, v.167, p.220-225, 2012. DOI: 10.1016/j.micres.2011.09.001.

LASLO, É.; GYÖRGY, É.; MARA, G.; TAMÁS, É.; ÁBRAHÁM, B.; LÁNYI, S. Screening of plant growth promoting rhizobacteria as potential microbial inoculants. Crop Protection, v.40, p.43-48, 2012. DOI: 10.1016/j.cropro.2012.05.002.

MENDONÇA, M. de; KASUYA, M.C.; CADORIN, A.; VIEIRA, A.J. Mushroom for a living: Agaricus blazei cultivation for a living in Brazil. In: SHIITAKE cultivation. Part II. Mushroom for better life. Seoul: MushWorld, 2005. p.208-218. (Mushroom growers' handbook, 2).

PARDO-GIMÉNEZ, A.; ZIED, D.C.; PARDO-GONZÁLEZ, J.E. Utilización de compost agotado de champiñón como capa de coberturas en nuevos ciclos de producción. Pesquisa Agropecuária Brasileira, v.45, p.1164-1171, 2010. DOI: 10.1590/ S0100-204X2010001000016.

POKHREL, C.P.; OHGA, S. Cattle bedding waste used as a substrate in the cultivation of Agaricus blazei Murill. Journal of the Faculty of Agriculture, v.52, p.295-298, 2007.

PROBANZA, A.; LUCAS GARCÍA, J.A.; RUIZ PALOMINO, M.; RAMOS, B.; GUTIÉRREZ MAÑERO, F.J. Pinus pinea L. seedling growth and bacterial rhizosphere structure after inoculation with PGPR Bacillus (B. licheniformis CECT 5106 and B. pumilus CECT 
5105). Applied Soil Ecology, v.20, p.75-84, 2002. DOI: 10.1016/ S0929-1393(02)00007-0.

SAHARAN, B.S.; NEHRA, V. Plant growth promoting rhizobacteria: a critical review. Life Sciences and Medicine Research, v.2011: LSMR-21, 2011.

SAKTHIVEL, M.; KARTHIKEYAN, N.; JAYAVENY, R.; PALANI, P. Optimization of culture conditions for the production of extracellular cellulase from Corynebacterium lipophiloflavum. Journal of Ecobiotechnology, v.2, p.6-13, 2010.

SARANGI, I.; GHOSH, D.; BHUTIA, S.K.; MALLICK, S.K.; MAITI, T.K. Anti-tumor and immunomodulating effects of Pleurotus ostreatus mycelia-derived proteoglycans. International Immunopharmacology, v.6, p.1287-1297, 2006. DOI: 10.1016/j. intimp.2006.04.002.

SESSITSCH, A.; HARDOIM, P.; DÖRING, J.; WEILHARTER, A.; KRAUSE, A.; WOYKE, T.; MITTER, B.; HAUBERG-LOTTE, L.; FRIEDRICH, F.; RAHALKAR, M.; HUREK, T.; SARKAR, A.; BODROSSY, L.; VAN OVERBEEK, L.; BRAR, D.; VAN ELSAS, J.D.; REINHOLD-HUREK, B. Functional characteristics of an endophyte community colonizing rice roots as revealed by metagenomic analysis. Molecular Plant-Microbe Interactions, v.25, p.28-36, 2012. DOI: 10.1094/MPMI-08-11-0204.

TILAK, K.V.B.R.; RANGANAYAKI, N.; PAL, K.K.; DE, R.; SAXENA, A.K.; NAUTIYAL, C.S.; MITTAL, S.; TRIPATHI,
A.K.; JOHRI, B.N. Diversity of plant growth and soil health supporting bacteria. Current Science, v.89, p.136-150, 2005.

YOUNG, C.C.; BUSSE, H.J.; LANGER, S.; CHU, J.N.; SCHUMANN, P.; ARUN, A.B.; SHEN, F.T.; REKHA, P.D.; KÄMPFER, P. Microbacterium agarici sp. nov., Microbacterium humi sp. nov. and Microbacterium pseudoresistens sp. nov., isolated from the base of the mushroom Agaricus blazei. International Journal of Systematic and Evolutionary Microbiology, v.60, p.854-860, 2010. DOI: 10.1099/ijs.0.014092-0.

YOUNG, L.-S.; CHU, J.-N.; YOUNG, C.-C. Beneficial bacterial strains on Agaricus blazei cultivation. Pesquisa Agropecuária Brasileira, v.47, p.815-821, 2012. DOI: 10.1590/ S0100-204X2012000600012.

YOUNG, L.-S.; HAMEED, A.; PENG, S.-Y.; SHAN, Y.H.; WU, S.P. Endophytic establishment of the soil isolate Burkholderia sp. CC-Al74 enhances growth and P-utilization rate in maize (Zea mays L.). Applied Soil Ecology, v.66, p.40-47, 2013. DOI: 10.1016/j.apsoil.2013.02.001.

ZARENEJAD, F.; YAKHCHALI, B.; RASOOLI, I. Evaluation of indigenous potent mushroom growth promoting bacteria (MGPB) on Agaricus bisporus production. World Journal of Microbiology and Biotechnology, v.28, p.99-104, 2012. DOI: 10.1007/s11274-011-0796-1.

Received on March 12, 2013 and accepted on May 29, 2013 